\title{
MAKNA PERSAHABATAN \\ SEBUAH TINJAUAN DARI PERSPEKTIF FILSAFAT
}

\section{J. Sudarminta}

\begin{abstract}
This article is meant to be a philosophical reflection on the meaning of friendship. As evident from its sub-titles, the article is divided into four parts. First, it deals with the notion of friendship, in which the genuine friendship, or in Aristotle's term called the perfect form of friendship, is distinguished from the egoistic or the imperfect forms. Referring to Aristotle's account of friendship, the perfect form of friendship is a friendship in which each friend values the other for their own particular qualities, for their own sake, for their virtuous character and not for the pleasure or utilities they can provide. The imperfect forms of friendship usually do not last long, because the tie of friendship will get loose and finally dissolved when it does not bring either pleasure or utilities each friend wants. Second, following Aristotle, I try to explain why friendship is considered important for human happiness. Third, the element of right and duty that get involved in the personal relation of friendship is being addressed. Finally, due to the increasing importance of online communication nowadays, especially during this pandemic corona virus outbreak, I would like also to address the opportunities and challenges of online friendship or the relation of friendship mediated by social media.In this regard, the opportunity to foster online friendship is bigger under the model of moral friendship according to Kant and Kierkegaard in which universal love is emphasized, and Nietzsche's model in which the agonistic nature of friendship is highly valued, than under the Aristotle's model.
\end{abstract}

Keywords: friendship, philosophical reflection, Aristotle, pleasure, utility, virtuous character, human happiness, right and duty, opportunities and challenges, online friendship, Kant, Kierkegaard, Nietzsche. 


\section{Abstrak}

Artikel ini dimaksudkan sebagai sebuah refleksi filosofis tentang makna persahabatan. Seperti nampak dari sub-judul, kajian dalam artikel ini dibagi menjadi empat bagian. Bagian pertama membahas tentang pengertian persahabatan dan merujuk pada tiga bentuk persahabatan yang dikemukakan oleh Aristoteles. Persahabatan yang sejati atau bentuk sempurna persahabatan dalam peristilahan Aristoteles, adalah bentuk persahabatan di mana masing-masing orang yang bersahabat menghargai yang lain demi kualitas atau keutamaan karakter sahabat pada dirinya. Sedangkan persahabatan yang berpamrih adalah persahabatan yang didorong oleh motitavasi mencari kesenangan atau keuntungan dari relasi persahabatan tersebut. Persahabatan jenis ini tidak seawet persahabatan yang sejati, karena begitu kesenangan dan keuntungan yang diharapkan itu sudah tidak diperoleh, maka persahabatan merenggang dan akhirnya bubar. Bagian dua menjelaskan mengapa, seperti sudah dikemukakan oleh Aristoteles, persahabatan itu penting bagi manusia dalam mencari kebahagiaan hidupnya. Ketiga, persoalan hak dan kewajiban dalam relasi persahabatan dicoba untuk diulas. Terakhir, mengingat dewasa ini kita hidup dalam zaman di mana komunikasi daring sangat penting, khususnya pada masa pandemi covid 19 ini, peluang dan tantangan persahabatan lewat komunikasi daring yang sangat ditunjang oleh semakin luasnya penggunaan media sosial, akan ditinjau. Dalam memupuk persahabatan online, model persahabatan moral yang ditekankan oleh Kant dan Kierkegaard di mana kasih universal pada orang lain, dan model persahabatan Nietzsche yang bersifat agonistik (berani terus terang menggugat sahabatnya dan berargumentasi agar kebenaran tersingkap) lebih mungkin dikembangkan dibandingkan model Aristoteles.

Kata kunci: persahabatan, refleksi filosofis, Aristoteles, kenikmatan, kegunaan, karakter berkeutamaan, kebahagiaan manusia, hak dan kewajiban, peluang dan tantangan, persahabatan daring, Kant, Kierkegaard, Nietzsche. 
Tema yang dipilih oleh Panitia Perayaan 50 tahun berdirinya STFT Widyasana, Malang, dalam menyelenggarakan hari studi bulan Oktober 2020 adalah "Kamu adalah Sahabatku." Sebagai dosen tamu yang pernah diundang untuk mengajar di lembaga pendidikan tersebut, saya diminta untuk ikut serta merefleksikan tema "Persahabatan." Mengingat bidang studi yang selama ini saya geluti adalah filsafat, maka saya bermaksud menyoroti makna persahabatan dari perspektif filsafat.Seperti dikatakan oleh Mark Vernon (Vernon 2007: 163), pembicaraan tentang persahabatan menyangkut pertanyaan-pertanyaan yang secara khusus dekat dengan pengalaman kebanyakan orang. Mark Vernon juga mengingatkan bahwa dalam situasi budaya zaman sekarang yang kuat dipengaruhi oleh nalar-instrumental dengan obsesinya pada manfaat atau kegunaan dalam menjalin relasi dengan orang lain, pembahassn tentang persahabatan juga perlu menyadari ambiguitas atau sifat menduanya. Di satu pihak persahabatan itu memang bernilai dalam hidup manusia, namun di lain pihak, relasi persahabatan dalam budaya zaman yang didominasi oleh nalar-instrumental, ada bahaya bahwa persahabatan dikooptasi oleh hukum produktivitas dan konsumsi, sehingga persahabatan hanya bersifat instrumental belaka. ${ }^{1}$

1 Seluruh buku Mark Vernon (The Philosophy of Friendship. New York: Pelgrave Macmillan, [2005] 2007, menyoroti lima macam ambiguitas yang menandai persahabatan, (1) ambiguitas persahabatan yang terjalin dalam relasi dunia kerja;di satu pihak persahabatan dalam dunia kerja itu bernilai, di lain pihak persahabatan dalam lingkungan dunia kerja dapat terkooptasi oleh kepentingan produksi dan konsumsi atau demi mengejar keuntungan semata; (2) ambiguitas persahabatan yang terjalin dalam kaitan dengan cinta dan seks; di satu pihak wajar bahwa daya tarik seksual dapat menjadi awal jalinan persahabatan, di lain pihak persahabatan yang sejati dan lestari tidak dapat didasarkan hanya pada daya tarik seksual belaka; (3) ambiguitas persahabatan terkait dengan unsur kepura-puraan yang tak terhindarkan dalam relasi persahabatan yang di satu pihak menuntut kejujuran dan kepercayaan, di lain pihak keterusterangan yang telanjang dapat menyakiti dan mengakhiri persahabatan; (4) ambiguitas persahabatan terkait dengan konsep cinta tanpa syarat; di satu pihak dalam relasi persahabatan perlu mengutamakan sahabat, dan di lain pihak tuntutan moral untuk mencintai semua orang; terkait ambiguitas keempat ini Vernon juga membahas tentang politik persahabatan (5) ambiguitas persahabatan terkait spiritualitas persahabatan yang didasarkan atas esai yang ditulis oleh Montaigne dan Emerson tentang "sahabat jiwa" (soul friendship) yang memandang seorang sahabat sebagai "belahan jiwa" (soul mate). Di satu pihak seorang sahabat, seperti dikatakan Aristoteles, dapat disebut sebagai "diri yang lain" (another self), di lain pihak seorang sahabat tetap merupakan suatu individu yang lain yang memiliki banyak perbedaan. 
Sejak zaman Yunani Kuno, Abad Pertengahan,Zaman Modern, hingga masa kini, tema persahabatan cukup banyak dibahas oleh para filsuf. ${ }^{2}$ Sebuah tinjauan dari perspektif filsafat, selain bersifat reflektif dan kritis, biasanya mengangkat persoalan yang bersifat umum, menyeluruh, dan mendasar. Persoalan yang umum, menyeluruh, dan mendasar terkait tema persahabatan

2 Dalam zaman Yunani Kuno, seperti tercermin dalam buku kumpulan Dialog Plato, Socrates menjalin persahabatan khusus dengan beberapa muridnya; dalam dialog Plato berjudul Lysis, fokus pembicaraan tokoh utama Socrates dengan dua pemuda yang menjadi lawan bicaranya adalah tentang persahabatan. Aristoteles membahas tema persahabatan baik dalam bukunya Eudemian Ethics maupun dalam buku VIII dan IX Nichomachen Ethics. Dalam awal Abad Pertengahan, Agustinus dalam Confessiones mengisahkan kepedihan hatinya ketika harus berpisah karena kematian sahabat dekatnya yang sudah seperti belahan jiwanya sendiri, suatu peristiwa yang membuat dirinya takut mati dan dihantui oleh fantasi kematian para sahabatnya yang lain. Refleksi Agustinus kemudian atas peristiwa itu menyadarkan dirinya bahwa ia telah mencintai sahabatnya yang meninggal itu melebihi cinta dia yang seharusnya pada Tuhan. "Betapa gilanya, mencintai seorang manusia sebagai suatu yang melampaui kemanusiaannya." Ia kemudian tidak lagi memandang penting persahabatan antar-manusia yang cenderung narsis dan mengutamakan persahabatan dalam Tuhan. Hanya Tuhan yang dapat mencintai tanpa syarat dan tidak akan mengecewakan. Gugatan Agustinus terhadap nilai persahabatan yang intim antar-manusia itu nantinya dalam zaman Modern dilanjutkan oleh Kierkegaard yang dalam bukunya Works of Love mengutamakan perintah Allah untuk mencintai orang lain (tetangga) seperti diri sendiri. Cinta terhadap orang lain (tetangga), bagi Kierkegaard, merupakan suatu bentuk cinta yang samasekali berbeda dengan cinta persahabatan antarmanusia. Cinta persahabatan antar-manusia memuat unsur cinta-diri, sedangkan cinta terhadap orang lain mengandaikan penyangkalan diri, bersifat altruistik, dan hanya dapat dilakukan kalau dihayati sebagai kepatuhan pada perintah Alllah. Cinta Kristiani mengajarkan untuk mencintai semua orang sebagaimana Allah mencintai manusia tanpa syarat.Pada Abad Pertengahan, Thomas Aquinas, dalam Summa Theologiae II, berusaha mengintegrasikan pemikiran Aristoteles yang memahami persahabatan sebagai suatu yang bersifat partikular dan berangkat dari cinta-diri dengan pandangan Kristiani tentang cinta pada orang lain atau cinta universal pada semua orang. Menurut Thomas Aquinas, kendati persahabatan dapat menguntungkan untuk diri sendiri atau orang lain, itu tidak berarti bahwa persahabatan yang menguntungkan untuk diri sendiri tidak sekaligus juga menguntungkan yang lain sebagai sahabatnya. Misalnya persahabatan yang didorong oleh motivasi mencari keuntungan atau kesenangan itu pertama-tama memang untuk diri sendiri, namun juga dapat mengandung unsur yang menguntungkan dan menyenangkan juga untuk orang yang dijadikan sahabat. Jenis persahabatan ini memang tidak mulia dalam keutamaan, namun juga tidak secara intrinsik jahat. Sedangkan persahabatan yang bersifat untuk orang lain, sesungguhnya juga membawa manfaat untuk diri sendiri. Unsur kedua yang dikemukakan Thomas Aquinas dalam mengintegrasikan cinta persahabatan dengan cinta Kristiani adalah bahwa cinta persahabatan bersifat cinta ilahi manakala cinta persahabatan itu tidak posesif dan egoistik, melainkan altruistik. Berbeda dengan Kierkegaard kemudian yang memandang cinta persahabatan antar- 
misalnya: Apa itu persahabatan? Mengapa persahabatan dipandang penting dan bernilai bagi hidup manusia? Apa bedanya antara persahabatan yang sejati/terbaik dan persahabatan yang berpamrih? Adakah unsur hak dan kewajiban dalam relasi persahabatan? Mengapa mengutamakan seorang sahabat di atas orang lain yang bukan sahabat itu secara etis dapat dipertanggungjawabkan? Apa dasar pertanggungjawabannya?

\author{
Dalam refleksi filosofis tentang persahabatan dalam tulisan ini saya \\ tidak akan menjawab semua pertanyaan filosofis tentang persahabatan di
}

\begin{abstract}
manusia itu bersifat mencari diri (selfish) dan melulu bersifat partikular, bagi Thomas Aquinas cinta persahabatan yang awalnya didorong oleh cinta-ciri dapat bertumbuh ke arah cinta altruistik ketika mau berkorban untuk sahabatnya, dan cinta persahabatan yang bersifat partikular tidak melulu eksklusif karena kandungan altruisme dalam cinta persahabatan dapat bertumbuh juga ke arah cinta yang universal dan inklusif. Kalau Kierkegaard mengajarkan agar orang Kristiani mencintai orang lain sebagai bentuk kepatuhan kepada perintah Allah, Thomas Aquinas mengajarkan cinta orang lain sebagai tanggapan terhadap kasih Allah yang sudah lebih dulu diberikan kepada manusia. Dalam zaman Modern, misalnya dalam pemikiran Immanuel Kant, cinta persahabatan yang bersifat partikular dan memuat unsur cinta-diri cenderung dicurigai dan secara moral dipandang tidak memadai. Kant membedakan antara persahabatan moral dan persahabatan berdasarkan rasa perasaan (I. Kant, The Metaphysics of Morals. Translated by Mary Gregor. Cambridge cambridge University Press, 1991, 261). Persahabatan moral bagi Kant merupakan ideal persahabatan yang dalam praktek tidak dapat dicapai, karena mengandaikan kesamaan cinta dan sikap hormat terhadap kedua belah pihak yang bersahabat. Konsep persahabatan Kant berbeda dengan konsep Aristoteles. Ideal persahabatan pada Atistoteles, seperti sudah disinggung di atas, adalah persahabatan antara orang-orang baik berdasarkan keutamaan atau karakter baik dari kedua pihak yang bersahabat. Ideal persahabatan Kant adalah adanya sikap hormat dan cinta timbal balik yang bersifat sama. Persahabatan model Aristoteles bersifat partikular, model Kant bersifat universal. Model Aristoteles mengandaikan hidup bersama dan melakukan kegiatan bersama, model Kant mengutamakan adanya keintiman berdasarkan cinta dan sikap hormat timbal balik serta kepercayaan satu sama lain dalam komitmen menjaga rahasia batin sahabatnya. Bagi Kant, dunia modern andalah dunia yang ditandai oleh masyarakat yang bersifat individualistik dan atomistik, masing-masing anggota memiliki kepentingan diri, sangat menekankan kebebasan, dan bersifat mudah pindah tempat (mobile). Dunia modern juga dunia yang tidak bersahabat dan sulit percaya satu sama lain. Kajian tentang persahabatan pada zaman kontemporer antara lain dilakukan oleh J. Derrida dalam tulisannya berjudul Politics of Friendship. Translated by George Collins, London and New York: Verso, 2005. Martha Nussbaum dalam bukunya The Fragility of Goodness: Luck and Ethics in Classical Tragedy and Philosophy, Cambridge and New York: Cambridge University Press, 1986 antara lain juga membahas tentang persahabatan, di mana ia menanggapi secara kritis konsep persahabatan Aristoteles yang cenderung elitis dan aristokratis karena menekankan kesamaan dalam persahabatan di antara orang-orang yang unggul atau berkeutamaan serta belum menyadari pentingnya perbedaan yang dapat memperkaya persahabatan.
\end{abstract}


atas. Supaya tidak terlalu melebar, saya ingin membatasi diri pada empat hal berikut: (1) Pengertian Persahabatan: Antara Persahabatan Yang Sejati dan Yang Berpamrih; (2) Pentingnya Persahabatan Bagi Manusia; (3) Unsur hak dan kewajiban dalam relasi persahabatan. Akhirnya, mengingat dewasa ini, apalagi pada masa pandemi covid 19 ini, relasi antar-manusia terpaksa banyak dilakukan secara daring, demikian juga dalam menjalin relasi persahabatan, maka pada akhir tulisan ini saya juga ingin secara khusus merefleksikan (4) Persahabatan Lewat Komunikasi Daring: Peluang dan Tantangannya.

\section{Pengertian Persahabatan: Antara Persahabatan Sejati dan Yang Berpamrih}

Sebagaimana tercermin dalam dialog Plato berjudul Lysis, pertanyaan "Apa itu Persahabatan?" atau dengan kata lain "Siapa itu seorang sahabat?" sudah menyibukkan pikiran Plato sejak zaman Yunani Kuno.Dalam dialog tersebut Socrates membuka percakapan dengan mengatakan bahwa sesungguhnya sejak muda ia ingin punya teman, tetapi "saya bahkan tidak tahu bagaimana seorang menjadi sahabat bagi yang lain" (212a5-6). Upaya mendefinisikan apa itu persahabatan, rupanya gagal dirumuskan, karena pada akhir percakapan dengan dua orang muda yang dia ajak bicara, Socrates mengakui bahwa "kita belum mampu menemukan apa sesungguhnya seorang sahabat itu" (223b7-8). Memang tidak ada definisi yang tunggal untuk persahabatan, karena ada banyak bentuk persahabatan.

Kendati tidak ada definisi tunggal untuk pengertian persahabatan karena ada banyak bentuk persahabatan, namun ada beberapa ciri pokok yang menandai dan dapat diidentifikasi dalam relasi persahabatan. Misalnya, pertama, relasi persahabatan adalah relasi yang secara bebas dipilih, dikembangkan, dan dicoba dirawat dalam perjalanan waktu oleh mereka yang bersahabat. Kedua, dalam relasi persahabatan ada rasa tertarik satu sama lain, saling menghormati dan menghargai, ada kerinduan untuk bertemu dan meluangkan waktu untuk kegiatan bersama. Ketiga, walaupun kadang dapat terjadi perbedaan pendapat dan bahkan konflik, namun selalu ada upaya untuk berdamai kembali dan merasa senang berada dalam 
kebersamaan. Keempat, relasi persahabatan yang sehat juga dapat saling memperkaya dan melengkapi satu sama lain, memberi otonomi atau ruang kebebasan bagi masing-masing untuk berkembang; tidak ingin memiliki dan menguasai (terlalu posesif dan dominatif) terhadap yang lain. Kelima, relasi persahabatan yang sejati membuka kemungkinan yang inspiratif dan mendukung bagi terjadinya kegiatan bersama, tukar menukar pengalaman, perasaan atau curahan hati, tukar pikiran dan pengetahuan, berbagi keterampilan dan cita-cita, rela berbagi suka dan duka serta berbagi kisah hidup. Keenam, persahabatan yang sejati dan lestari juga dapat saling mendukung dalam mengenal dan menerima diri, menyadari kekuatan dan kelemahan masing-masing lewat kritik dan umpan-balik yang diberikan secara jujur oleh sahabatnya, lewat penyingkapan kekuatan dan kemampuan yang selama ini mungkin masih tersembunyi oleh sahabat yang mengenal baik dirinya, relasi persahabatan juga dapat membantu mengembangkan diri. (Bdk. Emma Rooksby 2002: 138-139).

Dalam hidup sehari-hari kita mengenali adanya banyak bentuk persahabatan, masing-masing dengan kadar kedekatan dan kedalaman hubungan yang berbeda di antara orang yang bersahabat. Persahabatan antara teman-teman dalam satu sekolah atau satu kampung, antara temanteman sekerja di pabrik atau di perkantoran, antara pemilik usaha dan karyawannya karena hubungan kerja, antara orang-orang yang punya hobi yang sama, persahabatan yang muncul di antara kawan lama di asrama atau di sekolah setelah bereuni bersama. Bentuk-bentuk persahabatan tersebut memiliki kualitas relasi yang berbeda dengan persahabatan antara dua pribadi yang saling tertarik secara afektif, yang saling mencintai dan menghormati, serta saling melengkapi, yang merindukan dan merasa senang dalam kebersamaan dengan sahabatnya. Relasi persahabatan yang lebih mendalam biasanya ditandai oleh komitmen untuk saling membahagiakan satu sama lain, melakukan kegiatan bersama, rela berbagi waktu, harta kekayaan, dan pengetahuan, selalu siap sedia membantu di kala sahabatnya memerlukan bantuan, serta berusaha mengembangkan potensi dan hal-hal yang baik dalam diri sahabatnya.

Aristoteles memahami persabatan sebagai semacam keutamaan atau paling tidak melibatkan keutamaan (Nichomachean Ethics, Buku 
VIII, 1). ${ }^{3}$ Dalam bentuk persahabatan yang sejati, seperti masih akan kita lihat lebih jauh di bawah, Aristoteles menjelaskan adanya jalinan relasi afektif yang saling membahagiakan antara pasangan orang baik dan berkeutamaan yang bersahabat. Di dalamnya ada unsur hidup bersama dan melakukan kegiatan bersama selama beberapa waktu, sehingga dapat saling mengenal watak dan kepribadian masing-masing, tumbuh sikap saling percaya, dan mau berbagai waktu, milik, dan perhatian satu sama lain. Persahabatan yang sejati mendasarkan diri pada apa yang hakiki, yakni karakter atau keutamaan yang ada dalam diri sahabatnya, dan tidak hanya yang adanya bersifat insidental dalam diri pribadi yang menjadi sahabatnya. Persahabatan yang sejati, kendati, bagi Aristoteles tidak lepas dari cinta pada diri sendiri (self-love), namun tidak egoistik atau ego-sentrik, melainkan demi kebaikan pribadi orang yang menjadi sahabatnya (Nichomachean Ethics, Buku IX, 8).

Berdasarkan motivasi yang mendasari persahabatan, Aristoteles membedakan adanya tiga jenis persahabatan (Nichomachean Ethics, Buku VIII, 3 dan 6). Pertama, persahabatan berdasarkan guna atau manfaat; persahabatan jenis ini terbentuk karena pribadi yang dijadikan sahabat itu dirasakan berguna atau bermanfaat bagi dirinya. Dalam relasi persahabatan jenis ini, partner persahabatan tidak merasa tertarik atau memiliki afeksi terhadap sahabatnya pada dirinya, melainkan berdasarkan guna atau manfaat yang dapat ia peroleh dari sahabatnya itu. Misalnya seorang agen pemasok obat dari suatu perusahaan farmasi tertentu berusaha menjalin persahabatan dengan petugas penyedia obat-obatan di suatu Rumah Sakit, bukan karena pribadi petugas itu pada dirinya yang menarik perhatian agen pemasok obat tersebut untuk menjalin persahabatan dengan dia, melainkan karena kedekatan dengan orang itu membawa manfaat bagi penjualan obat yang ia lakukan. Dengan kata lain, kedekatan dengan orang itu menguntungkan bagi dirinya. Persahabatan jenis ini, biasanya tidak langgeng, karena begitu keuntungan yang diperoleh dari orang itu tidak lagi ia dapatkan, maka relasi persahabatan

3 Untuk tulisan ini saya mendasarkan diri pada buku Aristotle, Nichomachean Ethics. Translated with introduction and notes by Martin Ostwald, Indianapolis: Bobbs-Merill Educational Publishing, 1962. 
terhenti. Misalnya ketika petugas Rumah Sakit yang melakukan pembelian obat itu sudah ganti orang, maka agen penjualan obat itu sudah kehilangan alasan untuk tetap bersahabat dengan petugas pembelian yang lama.

Kedua, persahabatan berdasarkan kesenangan atau kenikmatan; persahabatan jenis ini terbentuk karena pribadi yang dijadikan sahabat itu dirasa mendatangkan kesenangan atau kenikmatan bagi dirinya. Misalnya si A mau bersahabat dengan si B, karena si B orangnya kaya dan suka mentraktir makan orang yang menjadi sahabatnya. Dengan demikian si A dapat memperoleh kesenangan atau kenikmatan dalam persahabatannya dengan si B. Inilah sebabnya mengapa orang kaya dan sukses hidupnya sering dikelilingi oleh banyak teman yang ingin memperoleh kesenangan dari relasi persahabatan dengan orang itu. Seperti halnya persahabatan berdasarkan manfaat di atas biasanya tidak langgeng, demikian juga jenis persahabatan yang terbentuk berdasarkan kesenangan ini. Begitu si B jatuh miskin dan tidak lagi dapat mentraktir makan orang yang menjadi sahabatnya, maka si A mundur dari persahabatan dengan si B dan bahkan menjauhinya karena tidak mau repot untuk harus membantu si B dalam kesusahannya. Aristoteles mencatat bahwa persahabatan di antara orang muda seringkali didasarkan atas kesenangan, karena hidup mereka sering masih banyak dipengaruhi oleh emosi atau perasaan, dan mereka mengejar apa yang menyenangakan bagi mereka. (Nichomachean Ethics, Buku VIII, 3, 1156b.5). Mereka juga mudah jatuh cinta, tetapi tidak selalu dapat bertahan dalam relasi cinta dengan orang yang dijatuhi cinta.

Kedua jenis atau bentuk persahabatan di atas, yang terbentuk dan dihayati berdasarkan motivasi kegunaan dan kesenangan, bukanlah persahabatan yang sejati atau sempurna menurut Aristoteles. Kedua jenis persahabatan di atas dapat dikatakan sebagai persahabatan yang berpamrih. Orang menjalin persahabatan karena ada pamrih mendapat keuntungan atau kesenangan dalam persahabatan tersebut. Semua bentuk persahabatan yang berpamrih biasanya akan menjadi renggang dan bahkan putus, ketika apa yang menjadi objek pamrih yang dituju, entah itu kegunaan atau kesenangan, sudah tidak dapat diperoleh lagi dari jalinan persahabatan tersebut. Maka persahabatan yang berpamrih biasanya tidak dapat lestari, karena hanya 
akan berlangsung sejauh objek pamrihnya masih mungkin diperoleh. Bentuk persahabatan yang berpamrih, entah demi kegunaan atau pun demi kesenangan, juga bisa terjadi antara orang jahat; mereka dapat menjalin persahabatan dengan orang yang mereka pandang berguna dan dapat memberi kenikmatan. Begitu tidak lagi berguna dan tidak memberi kenikmatan, maka jalinan persahabatan itu diputus.

Ketiga, persahabatan yang sejati atau dalam peristilahan Aristoteles disebut bentuk sempurna persahabatan (Nichomachean Ethics, Buku VIII, $3,1156 \mathrm{~b} .10$ ), adalah persahabatan yang terjalin antara orang-orang yang baik yang sama-sama unggul atau berkeutamaan. Mereka yang bersahabat dalam bentuk ketiga ini sama-sama mengharapkan apa yang baik dalam arti sesungguhnya bagi sahabatnya. Sikap mereka ditentukan oleh karakter atau keutamaan sahabatnya, dan bukan oleh suatu yang bersifat insidental dalam diri sahabatnya. Maka persahabatan yang sejati atau sempurna itu akan langgeng atau lestari karena kebaikan dan keutamaan itu bersifat lestari. Dalam bentuk persahabatan yang sempurna, pasangan orang yang bersahabat masing-masing baik tanpa kualifikasi, dan baik untuk sahabatnya. Keduanya saling berbuat baik terhadap yang lain. Persahabatan yang sejati atau sempurna, dengan sendirinya juga merupakan suatu bentuk persahabatan yang bermanfaat dan menyenangkan bagi satu sama lain dalam relasi persahabatan tersebut; tetapi persahabatan yang sejati tidak dimotivasi oleh dorongan untuk memperoleh manfaat atau pun kesenangan. Menurut Aristoteles, dalam persahabatan sejati sebagai persahabatan antara orangorang baik, rasa afeksi dan persahabatan hadir dalam bentuk yang paling tinggi dan paling baik (Nichomachean Ethics, Buku VIII, 3, 1156b.20). Bentuk persahabatan seperti itu tentu saja jarang terjadi, karena orang yang sungguh baik atau unggul dalam keutamaan itu hanya sendikit, dan memerlukan waktu untuk hidup bersama dan pembiasaan satu sama lain untuk sungguh saling mengenal dan percaya satu sama lain. (Nichomachean Ethics, Buku VIII, 3, 1156b.25). Aristoteles juga berpendapat bahwa bersahabat dengan banyak orang dalam bentuk persahabatan yang sempurna itu mustahil, karena mustahil juga untuk jatuh cinta dengan banyak orang sekaligus (Nichomachean Ethics, Buku VIII, 6, 1158a.10). 


\section{Pentingnya Persahabatan Bagi Manusia}

Dalam Etika Nichomachean Buku VIII, Aristoteles memulai pembahasan tentang persahabatan dengan mengajukan pertanyaan: "Mengapa kita memerlukan sahabat?" Jawaban dia adalah bahwa persahabatan itu "most indispensable for life. No one would choose to live without friends, even if he had all other goods." (Nichomachean Ethics, Buku VIII, 1.5). Bagi Aristoteles, orang kaya dan orang yang memiliki kekuasaan pun, lebih dari yang lain, memerlukan para sahabat. Sebab, apalah artinya kekayaan mereka kalau tidak memberi peluang bagi perbuatan baik, dan perbuatan baik yang layak dipuji adalah perbuatan baik yang dilakukan bagi para sahabatnya. Kekayaan dapat dijamin keamanannya dan dijaga kalau orang kaya punya banyak sahabat. Adanya sahabat bagi orang yang memiliki kekuasaan juga merupakan peluang bagi mereka untuk melakukan tindakan yang luhur. Aristoteles mengutip pernyataan Homerus yang menyatakan bahwa ketika dua orang pergi bersama-sama, teman-teman meningkatkan kemampuan kita untuk berpikir dan bertindak. (Nichomachean Ethics, Buku VIII, 1.15). Ketika orang bepergian ke luar negeri, ia dapat mengalami dengan mata kepala sendiri betapa orang dapat dekat dan bersahabat satu sama lain, karena samasama berada di tanah asing; cinta sesama merupakan suatu yang luhur. Persahabatan antar-warga dalam suatu negara, bagi Aristoteles, juga merupakan suatu yang memungkinkan terjadinya hidup bersama yang selaras dalam masyarakat. Ketika warga masyarakat saling bersahabat, atau ada kesepakatan ("concours") dalam hidup bersama, maka suasana damai dan keadilan akan lebih terjamin. Mengingat keadilan yang sempurna itu tak mungkin tercapai, maka adanya persahabatan di antara para warga negara, dalam bentuk sama-sama memiliki jiwa patriotik terhadap satu sama lain dan terhadap tanah air, merupakan suatu yang hakiki untuk menghindarkan dari klaim yang bertentangan antara para warga berkembang menjadi perang saudara. Dalam pandangan Aristoteles, persahabatan itu tidak hanya menggarisbawahi keadilan, melainkan juga memuat keadilan dan melampauinya. "Di mana ada persahabatan, tidak perlu lagi keadilan, tetapi bilamana mereka berlaku adil, mereka masih 
memerlukan persahabatan." (Nichomachean Ethics Buku VIII.1. 1155a 26-27). ${ }^{4}$

Persahabatan menurut Aristoteles juga merupakan suatu yang"luhur dan perlu: kita memuji mereka yang mencintai sahabat mereka dan menilai bahwa memiliki banyak teman itu suatu yang luhur." ("friendship is noble as well as necessary: we praise those wo love their friends and consider the possession of many friends a noble thing." - Nichomachean Ethics, Buku VIII, 1.1155a30). Persahabatan bagi Aristoteles merupakan suatu yang diperlukan manusia karena hal itu selaras dengan kodrat alami manusia sebagai makhluk sosial (zoon politicon). Manusia tidak dapat hidup sendirian. Ia memerlukan manusia lain untuk dapat hidup dan berkembang. "Kodrat alami sepertinya menanamkan persahabatan dalam diri orangtua untuk keturunannya dan dalam keturunan untuk orangtuanya; hal itu terjadi tidak hanya di antara manusia, melainkan juga di antara burung-burung dan kebanyakan binatang. Bukan hanya pada anggota kelompok keluarga yang sama, melainkan juga anggota ras yang sama, khususnya di antara manusia, merasakan adanya semangat persahabatan, dan itulah sebabnya kita memuji orang yang memiliki rasa kemanusiaan atau menjadi pencinta sesama manusia." ( Nichomachean Ethics, Buku VIII, 1. 1155a 15-20).

Aristoteles juga melihat pentingnya persahabatan dalam kaitan dengan kebahagiaan manusia. (Nichomachean Ethics, Buku IX. 9. 1169a 4-1170a 1-1170b 1-19). Seluruh pembahasan tentang persahabatan oleh Aristoteles ditempatkan dalam bukunya tentang Etika Eudaimonia, atau Etika Kebahagiaan. Dalam membahas kaitan antara persahabatan dan kebahagiaan, Aristoteles mulai dengan menanggapi persoalan apakah orang yang bahagia masih perlu sahabat. Ada pandangan bahwa orang-orang yang sungguh bahagia dan cukup-diri tidak memerlukan sahabat, karena mereka sudah memiliki hal-hal yang baik dalam hidup mereka. Pandangan ini,menurut Aristoteles, rasaya aneh, "karena kita semestinya menempatkan

4 Aristoteles juga membahas tentang kaitan antara persahabatan dan keadilan dalam negara (Nichomachean Ethics, Buku VIII, 9.1159b 25-1160a 1-30). Ia juga membahas kaitan antara persahabatan dan keadilan dalam sistem politik yang berbeda (Nichomachean Ethics, Buku VIII, 9.11.1161a 10-1161b 1-10). 
semua yang baik pada orang yang bahagia, tetapi tanpa memasukkan persahabatan di dalamnya; padahal persahabatan merupakan kebaikan eksternal yang terbesar. Juga kalau fungsi seorang sahabat adalah untuk melakukan kebaikan daripada untuk diperlakukan dengan baik, kalau tindakan melakukan perbuatan baik menandai orang baik dan berkeutamaan, dan apabila merupakan suatu yang lebih luhur melakukan kebaikan pada seorang sahabat daripada pada orang asing, maka orang dengan standar moral yang tinggi akan memerlukan [sahabat sebagai] orang kepada siapa ia dapat berbuat baik. " (Nichomachean Ethics, Buku IX. 9.1169b 8-16.)

Bagi Aristoteles rasanya juga aneh kalau orang yang sungguh bahagia itu hidup sendirian dalam isolasi. Tak seorangpun memilih untuk memiliki semua hal yang baik hanya untuk dirinya sendiri, karena manusia itu makhluk sosial dan politis, dan kondisi alaminya adalah hidup bersama yang lain. Oleh karenanya, orang yang bahagia juga memerlukan masyarakat. Karena ia memiliki apa yang secara kodrati baik, jelas lebih baik baginya untuk menghabiskan hari-hari hidupnya bersama sahabat-sahabat dan orang-orang baik daripada menghabiskan waktu hidupnya dengan orang-orang asing yang kebetulan datang atau lewat. Maka dari itu orang yang bahagia memerlukan sahabat-sahabat. Pandangan bahwa orang yang sudah bahagia tidak memerlukan sahabat, menurut Aristoteles, dapat muncul kemungkinan karena kebanyakan orang memahami persahabatan dalam bentuk yang menguntungkan atau menyenangkan, padahal orang yang sungguh bahagia tidak memerlukan sahabat yang melulu terdorong oleh motivasi mencari untung dari orang itu. Ia juga tidak memerlukan sahabat demi memperoleh kesenangan atau kenikmatan dari orang itu.

Kebahagiaan dalam pandangan Aristoteles merupakan suatu aktivitas, dan sebagai aktivitas, kebahagiaan itu jelas suatu yang muncul dari apa yang sebelumnya tidak ada, dan tidak dapat diandaikan adanya begitu saja layaknya sebuah harta milik yang sudah dipegang. Orang yang sungguh bahagia akan memerlukan sahabat-sahabat, yakni orang-orang yang memiliki standar moral tinggi dan menyenangkan; mereka memiliki kebaikan berupa kualitas karakter atau keutamaan yang mencerminkan kualitas karakter atau keutamaannya sendiri sebagai orang yang baik dan bahagia. Seandainya orang yang sungguh bahagia itu tanpa sahabat dan hidup sendirian dalam 
isolasi, maka hidupnya lalu juga terasa berat dan tidak menyenangkan. Tidak mudah untuk terus melakukan aktivitas sendirian; lebih mudah melakukan aktivitas bila ditemani atau dalam relasi dengan sahabat. Dengan hidup bersama orang-orang baik yang memiliki keutamaan atau keunggulan, orang juga dapat memperoleh semacam latihan dalam hal keutamaan atau keunggulan tersebut. Merupakan suatu yang alami bahwa orang yang secara moral baik ingin bersahabat dengan orang yang secara moral juga baik.

\section{Unsur hak dan kewajiban dalam relasi persahabatan}

Seperti pernah dikemukakan oleh James O. Grunebaum, (Grunebaum 2003: 4), menganalisis persahabatan melulu dalam terminologi hak dan kewajiban merupakan suatu yang menyesatkan, karena relasi persahabatan selalu memuat unsur kasih kepedulian dan kehendak baik pada sahabat yang melampaui hak dan kewajiban. Ketika seseorang menjalin persahabatan dengan orang lain, ia tidak akan pertama-tama bertanya dan mengutamakan apa yang menjadi hak dan kewajibannya dalam relasi persahabatan tersebut.Seorang sahabat yang baik akan terdorong dari dalam untuk berusaha menolong sahabatnya yang sedang mengalami kesulitan atau kesusahan tanpa bertanya apakah hal itu merupakan kewajiban dirinya sebagai seorang yang sahabat. Kalau ada sahabat yang mengalami kesulitan dan meminta tolong, seorang sahabat yang baik juga tidak akan menolak permintaan tolong sahabatnya itu dengan alasan bahwa sahabatnya tidak punya hak untuk meminta pertolongannya.

Walaupun demikian, dalam relasi persahabatan sesungguhnya juga termuat unsur hak dan kewajiban yang perlu disadari dan diperhatikan oleh mereka yang menjalin relasi persahabatan dengan orang lain. Ketika dalam relasi persahabatan seseorang perlu mendahulukan atau mengutamakan sahabatnya terlebih dulu dibanding orang lain, di situ termuat unsur hak dan kewajiban yang melekat pada relasi persahabatan. Bahwasanya kita mempunyai kewajiban tertentu kepada para sahabat kita, dan bahwa kita wajib memperlakukan sahabat kita dengan perlakuan tersendiri dan berbeda dengan yang bukan sahabat, merupakan suatu pandangan yang cukup umum dalam banyak lingkungan budaya. Pandangan itu mengimplikasikan bahwa 
kita mempunyai kewajiban yang lebih besar untuk menolong sahabat kita daripada orang yang sama sekali tidak kita kenal. Kewajiban kita untuk tidak berlaku jahat terhadap sahabat kita lebih besar daripada kewajiban kita untuk memenuhi prinsip moral dasar tidak berbuat jahat pada umumnya kepada setiap orang. Mungkin orang menolong sahabatnya bukan karena merasa ada kewajiban untuk itu, tetapi tetap saja unsur kewajiban melekat pada suatu relasi persahabatan. Sebagai bagian dari komitmen dirinya dalam menjalin relasi persahabatan, sahabat sejati sepertinya mewajibkan dirinya untuk menjadi orang yang dapat diandalkan oleh sahabatnya, ia berusaha selalu siap sedia menolong dan bersedia berada bersama sahabatnya ketika ia memerlukannya. Hal itu misalnya tercermin dalam ucapan a friend in need is a friend indeed. Kepada seorang sahabat kita diharapkan selalu dapat mengatakan: "kamu selalu dapat menaruh kepercayaan padaku" (you can always count on me).

Konsep hak dalam relasi persahabatan tentu saja bukan konsep hak yang bersifat legal, tetapi bersifat moral. Konsep hak yang bersifat legal biasanya muncul berdasarkan kontrak perjanjian legal yang pelaksanaannya dapat dituntut dan pelanggarannya dapat dikenai sanksi oleh pihak yang berwenang. Sedangkan konsep hak yang bersifat moral mendasarkan diri pada komitmen moral pihak-pihak yang bersangkutan. Konsep hak moral ini mirip hak yang muncul karena orang sudah berjanji atau berkaul. Pihak kepada siapa kita berjanji atau berkaul, secara moral berhak mengaharapkan bahwa kita memenuhi apa yang kita janjikan atau kaulkan. Dalam hal persahabatan, berarti komitmen moral antara dua pribadi yang menjalin persahabatan. Kendati hak untuk memperoleh perhatian dan pertolongan dari sahabatnya, ketika seseorang mengalami kesusahan dan penderitaan, tidak dapat dituntut secara legal, namun secara moral ia dapat mengharapkan, dan itu secara moral dinilai wajar, bahwa sahabatnya berkewajiban atas dasar ikatan persahabatannya untuk menolongnya. Seorang sahabat yang walaupun sesungguhnya mampu menolong, tetapi sengaja mengabaikan teriak minta tolong sahabatnya yang sedang terpuruk mengalami kesusahan dan penderitaan, secara moral dinilai gagal dalam memenuhi kewajibannya. Pribadi yang hatinuraninya masih berfungsi pasti akan merasakan adanya rasa bersalah (guilty feeling) kalau sampai mengabaikan kewajiban dan 
tanggung jawabnya terhadap sahabatnya; apalagi kalau ketika ia sendiri mengalami kesusahan, sahabat itu sudah lebih dulu berbuat baik terhadapnya.

\section{Persahabatan Lewat Komunikasi Daring: Peluang dan Tantangannya}

Dewasa ini kita hidup dalam zaman yang ditandai oleh semakin besarnya peran komunikasi daring lewat penggunaan teknologi digital dalam berbagai kegiatan, di berbagai bidang kehidupan guna memenuhi berbagai kebutuhan. Secara khusus dengan merebaknya pandemi covid 19 yang menimpa seluruh dunia belakangan ini, karena isolasi mandiri lintas negara, lintas komunitas, dan lintas kelompok atau pun keluarga, karena pembatasan sosial berskala besar, terpaksa dalam melakukan berbagai kegiatan yang diperlukan, baik itu komunikasi antar-negara, antar-rekan usaha, antarkomunitas, antar-kelompok, dan antar-pribadi, baik untuk urusan kerja, bisnis, belanja, pembelajaran, melakukan penelitian, mencari hiburan dan juga dalam menjalin persahabatan dilakukan lewat komunikasi daring. Beberapa provider yang menyediakan aplikasi untuk dapat melakukan komunikasi daring, seperti zoom-meetings, lark-meetings, google-meet, microsoft-team, google-class room, video-chat, skype,dsb menjadi banyak dicari dan digunakan orang.

\subsection{Peluang}

Semakin meluasnya penggunaan situs jejaring sosial dengan berbagai aplikasi yang tersedia dalam media sosial sepert WhatsApp, Facebook, Twitter, Instagram, Friendster, WeChat, MySpace, HalloDocuntuk berkomunikasi dalam berbagai keperluan menyangkut hubungan orangtuaanak, antar rekan kerja, antara pemberi kerja dan pekerja, antara guru dan siswa atau dosen dan mahasiswa, antara penjual dan pembeli, antar-alumni suatu sekolah atau perguruan tinggi, antar-teman asrama, dokter dan pasien, juga memberi peluang bagi upaya menjalin persahabatan secara daring. Berkat teknologi digital yang dewasa ini banyak dipakai, seperti telpon pintar, Ipad, Tablet dan Personal Computer, masih ditambah semakin luasnya 
ketersediaan jaringan internet, peluang untuk menjalin relasi persahabatan lewat komunikasi daring dapat dikatakan secara dramatis semakin diperluas pula.Dalam masyarakat modern yang warganya semakin banyak bergerak kemana-mana (mobile), entah karena urusan pekerjaan atau pun turisme, situs jejaring sosial memungkinkan anggota keluarga, sahabat dan teman berpeluang untuk tetap berkomunikasi secara cukup intensif dan dapat memberi kehangatan emosional tersendiri. ${ }^{5}$ Orang dengan mudah dapat saling berbicara, berkirim teks berita, informasi, foto tentang kegiatan yang dilakukan kepada sahabatnya dengan sangat cepat walaupun berada di belahan bumi yang lain.Selain komunikasi daring lewat berbagai situs jejaring sosial berpotensi membuka kemungkinan menjalin persahabatan baru, tali persahabatan yang mungkin sudah terjalin secara luring (off-line) masih terus dapat dipupuk dan dipererat lewat komunikasi daring (on-line). Berkat adanya komunikasi lewat grup WhatsApp antar kawan lama di asrama atau di sekolah menengah dulu ketika masih muda, suatu kegiatan reuni setelah puluhan tahun tidak bertemu, dapat menumbuhkan kembali relasi persahabatan yang sempat kendor karena lama tidak ada komunikasi. Setelah bertemu dalam reuni, komunikasi secara daring memberi peluang untuk terus merawat relasi persahabatan tersebut, kendati tinggal di kota atau pulau, atau bahkan di negara yang berbeda.

Berbagai organisasi, baik yang berorientasi mencari keuntungan maupun yang tidak, seperti organisasi kelompok mahasiswa, para ilmuwan dan peneliti, organisasi sosial yang mengupayakan program pemberdayaan sosial di berbagai negara, organisasi keagamaan, banyak memanfaatkan situs jejaring sosial untuk menghimpun anggota, menggalang dukungan dan merekrut anggota baru. Termasuk di sini kaum teroris yang banyak memakai komunikasi daring untuk mencari dan merekrut anggota baru. Komunikasi daring antara pribadi-pribadi yang terlibat dalam berbagai organisasi itu tidak jarang juga membentuk jaringan persahabatan yang mempermudah hubungan kerjasama di antara mereka. Dalam kaitan dengan upaya membangun solidaritas sosial menggalang dana selama pandemi covid 19 untuk membantu

5 Charles Ess, Digital Media Ethics. Cambridge, UK: Polity Press, 2014, h. 121. 
banyak Rumah Sakit yang kekurangan alat pelindung untuk para tenaga kesehatan, seperti APD, masker, face-shield, vitamin, sanitizer serta bantuan logistik lain bagi mereka yang miskin dan menderita, komunikasi daring lewat berbagai situs jejaring sosial ternyata dapat sangat membantu. Persahabatan di antara mereka yang terlibat dalam kegiatan menggalang dana dapat terjalin melampaui batas-batas suku, agama, ras, golongan, gender, klas sosial, dan bahkan lintas bangsa dan negara; semuanya terdorong oleh keprihatinan moral yang sama untuk memenuhi panggilan kemanusiaan menolong orang yang mengalami kesusahan. Situs jejaring sosial memberi peluang untuk menyebarluaskan informasi secara cepat, tepat, mudah, relatif murah dan berjangkauan luas. Rapat-rapat koordinasi juga dapat dilakukan secara daring dengan berbagai aplikasi pertemuan daring yang tersedia.

Seperti dinyatakan oleh Soraj Hongladarom (Hongladarom 2016: 127130) komunikasi daring lewat berbagai aplikasi yang tersedia dalam situs jejaring sosial memberi peluang untuk menjalin bentuk persahabatan yang menekankan cinta universal (mencintai orang lain seperti diri sendiri) sebagaimana ditekankan oleh Kierkegaard, dan bentuk persahabatan yang berani berterus terang terhadap sahabatnya guna menyingkapkan kebenaran dengan membuka kedok-kedok kepalsuan dalam diri sahabatnya supaya ia dapat mengembangkan dirinya dan semakin menjadi manusia unggul (Uebermensch) sebagaimana ditekankan oleh F. Nietzsche. Berbeda dengan model persahabatan Aristoteles yang mengandaikan kedekatan fisik yang memungkinkan hidup bersama, melakukan kegiatan bersama, pengenalan secara lebih mendalam satu sama lain, serta perlunya waktu yang dialami bersama bagi tumbuhnya pengenalan dan sikap saling percaya satu sama lain, cinta universal yang ditekankan oleh Kierkegaard dan sebelumnya juga oleh I. Kant dalam konsepnya tentang persahabatan moral (Lihat Catatan Kaki no. 4), komunikasi tidak perlu bersifat langsung tatap-muka dan mengandaikan hidup bersama serta melakukan kegiatan yang sama. Membangun relasi persahabatan lewat komunikasi daring justru dapat melampaui batas-batas geografis, batas suku, agama, ras, gender, klas sosial, bangsa dan negara. Komunikasi daring dapat menunjang terbentuknya kewargaan global dan tumbuhnya cinta universal. Lewat diskusi dan debat terbuka antar sahabat secara daring guna menggugat kemapanan pendapat 
masing-masing (persahabatan yang bersifat agonistik), penyingkapan kebenaran yang dicita-citakan dalam model persahabatan F. Nietzsche juga dimungkinkan, karena orang dapat dilepaskan dari sikap sungkan atau "ewuh pekewuh" dalam hubungan langsung secara tatap-muka dengan sahabatnya.

Dibandingkan dengan model persahabatan lewat surat-menyurat langsung model Montaigne dan Erasmus (Rooksby 2002: 147-157; Vernon 2007: 149-153), persahabatan lewat komunikasi daring, jauh lebih efisien karena informasi dapat saling dipertukarkan secara cepat, tepat, dan luas. Komunikasi daring dengan berbagai aplikasi yang tersedia dewasa ini juga memungkinkan terjadinya komunikasi yang interaktif antar-sahabat. Yang dipertukarkan bukan hanya informasi dalam bentuk tertulis, tetapi juga gambar, foto, dan video. Perpaduan antara teks, suara, gambar yang mati dan yang hidup dapat dengan mudah dilakukan oleh teknologi informasi dan komunikasi digital. Tidak seperti model persahabatan lewat surat-menyurat langsung yang harus menunggu berminggu-minggu atau bahkan berbulan-bulan untuk mendapatkan balasan berita dari sahabatnya yang berada di tempat yang jauh, kini dalam waktu yang singkat dan dalam ruang virtual yang sama, jawaban atau tanggapan dari sahabat itu sudah dapat diperoleh dan langsung dapat ditanggapi balik.

\subsection{Tantangan}

Kendati, seperti sudah kita lihat, relasi persahabatan lewat komunikasi daring memberi cukup banyak peluang yang berharga dalam membangun, merawat, dan mengembangkan persahabatan, namun ada beberapa keterbatasan tertentu yang dapat merupakan tantangan yang harus dihadapi, khususnya oleh mereka yang relasi persahabatannya hanya mendasarkan diri pada komunikasi daring. Kalau komunikasi daring bukan sebagai satusatunya sarana utama dalam membangun, merawat dan mengembangkan persahabatan, melainkan sebagai penunjang dan pelengkap relasi perjumpaan langsung, maka komunikasi daring yang ditunjang oleh kemajuan teknologi informasi dan komunikasi dewasa ini sungguh dapat lebih memperkaya dan memperluas jangkaun persahabatan antar umat manusia. Kalau relasi persahabatan hanya mendasarkan diri pada komunikasi daring, maka 
beberapa keterbatasan berikut perlu mendapat perhatian karena merupakan tantangan bagi kualitas persahabatan yang dihasilkan.

Keterbatasan yang sekaligus merupakan tantangan pertama adalah kemungkinan terjadinya salah paham antar-sahabat karena salah-tafsir atas pesan-pesan, baik secara tekstual, piktorial, dan auditif, yang dipertukarkan. Kualitas jaringan transmisi dalam sistem komunikasi daring yang dipakai pun akan memengaruhi apa yang dalam kenyataan dapat ditangkap atau diterima oleh masing-masing pihak yang berkomunikasi. Penyampaian pesan virtual lewat komunikasi daring membatasi orang untuk menangkap hal-hal yang biasanya dapat ditangkap dalam komunikasi langsung, seperti reaksireaksi spontan non verbal, raut wajah, nada suara dengan tekanan yang berbeda-beda, gerak-gerik tubuh yang sering dapat menyingkapkan lebih jauh siapa sesungguhnya si pengirim pesan, apa yang sedang memenuhi hati dan pikirannya, serta apa yang dimaksudkan dengan ungkapan-ungkapan yang disampaikan. Dalam komunikasi daring, pemilihan kata yang dipakai, baik secara tertulis maupun lisan, biasanya sudah lebih banyak ditata secara sadar oleh penulis atau pembicara, daripada kata-kata yang dipakai secara lebih spontan dalam komunikasi langsung. Dalam komunikasi daring orang masih lebih mungkin menyaring apa dari rahasia batin dirinya yang tidak ingin diungkapkan daripada dalam komunikasi langsung secara tatap muka. Dengan ini seringkali keaslian orang tidak langsung nampak dan salah paham karena salah tafsir maksud masing-masing juga mudah terjadi.

Keterbatasan dan sekaligus tantangan kedua relasi persahabatan lewat komunikasi daring adalah kemungkinan orang menggunakan akun dan identitas palsu tanpa langsung ketahuan. Kedirian seseorang yang tampil dalam situs jejaring sosial bisa jadi tidak autentik, sehingga pihak yang diajak berkomunikasi secara daring dalam proses menjalin persahabatan dapat memperoleh gambaran yang keliru tentang pasangan komunikasi yang ingin dia jadikan sahabat dalam jaringan virtual. Hal itu misalnya tercermin dalam ungkapan keheranan: "Mengapa wajah anda ternyata begitu berbeda dengan wajah yang terpapar dalam profil foto anda?" Karena kemungkinan terjadinya pemalsuan identitas lewat akun palsu ini bisa terjadi, maka kemungkinan orang dapat tertipu dalam relasi persahabatan lewat komunikasi 
daring juga dapat saja terjadi. Lalu orang menjadi sakit hati dan merasa dipermainkan oleh pasangan komunikasi daringnya.

Keterbatasan dan sekaligus tantangan ketiga dalam relasi persahabatan lewat komunikasi daring adalah menyangkut kerahasiaan pribadi yang kurang terjamin (the problem of privacy), baik menyangkut rahasia relasi persahabatan antara dua pribadi yang bersahabat itu sendiri maupun rahasia pribadi masing-masing orang yang bersahabat. Alasannya adalah walaupun antar-sahabat diharapkan dapat saling menyimpan rahasia, apa pun yang sudah diunggah ke situs jejaring sosial, mungkin saja ada orang yang meretas, dan yang berniat jahat kemudian menyalahgunakan untuk mempermalukan atau memeras orang yang bersahabat dan memiliki rahasia itu. Apalagi, ketika rahasia pribadi sudah terlanjur beredar secara viral, banyak orang secara cepat dan luas akan mengetahui rahasia pribadi tersebut. Apa yang sudah secara viral beredar di media sosial, sudah sulit sekali untuk dikendalikan atau ditarik kembali. Mengingat dalam relasi persahabatan yang sudah cukup intim satu sama lain dan kedua pribadinya sudah saling percaya satu sama lain, saling berbagi rahasia pribadi itu hal yang wajar, kemungkinan rahasia pribadi itu bocor keluar dan menjadi viral karena penyampaiannya dimediasi oleh media sosial, bukan suatu hal yang mustahil terjadi. Walaupun kerahasiaan komunikasi antar-sahabat itu sering dilindungi oleh sistem enskripsi dalam aplikasi yang dipakai, namun kebocoran, seperti terjadi dengan kasus Cambridge Analitica terkait Facebook sebagai provider atau penyedia layanan, bisa saja terjadi provider menyalahgunakan data besar (big-data) yang dimilikinya demi kepentingan tertentu, entah bisnis atau pun politis.

\section{Penutup}

Demikianlah beberapa catatan tentang persahabatan yang dapat saya bagikan pada kesempatan ini. Terima kasih atas undangan sebagai salah satu sahabat lama untuk ikut serta dalam hari studi dalam rangka memperingati 50 tahun perjalanan pelayanan Sekolah Tinggi Filsafat dan Teologi WidyaSasana. Kalau dibandingkan dengan masa ketika saya sempat diundang mengajar sebagai dosen tamu pengganti sementara Alm. Rm. Dr. 
Reksosusilo, CM karena beliau cuti di Solomon Island tahun 1989, STFT Widya Sasana kini sudah jauh lebih berkembang, bahkan sudah memiliki Program Studi S-2 dan S-3 yang diselenggarakan di gedung Pascasarjana yang megah, serta cukup banyak dosennya pun sudah menjadi Guru Besar. Kiprahnya di tengah masyarakat dan Gereja, baik lewat pelayanan pastoral maupun lewat buku dan artikel yang ditulis para dosennya, serta keterlibatan mereka dalam berbagai percaturan intelektual dan budaya dalam berbagai forum, sudah semakin dirasakan banyak orang. Akhir kata Dirgahayu Sekolah Tinggi Filsafat dan Teologi Widya Sasana. Tuhan memberkati dan Ad multos annos!

\section{KEPUSTAKAAN}

Aquinas, Thomas. (2006). Summa Theologiae. Latin Text and English Translation by Thomas Gilby, O.P. Cambridge, UK: Cambridge University Press.

Aristotle, (1962). Nichomachen Ethics. Translated with introduction and notes by Martin Ostwald, Indianapolis: Bobbs-Merill Educational Publishing.

Augustine, (2001). The Confessions of St. Augustine. Translated by Rex Warner, New York: Signet Classic.

Badhwar, Neera Kapur (Ed). (1993). Friendship. A Philosophical Reader. Ithaca, N.Y.: Cornell University Press.

Chambers, Deborah. (2013). Social Media and Personal Relationships: Online Intimacies and Networked Friendships. London: Palgrave Macmillan.

Derlega, Valerian J. \& Barbara A. Wisnstead (Eds.)(1986). Friendship and Social Interaction. New York: Springer Verlag.

Elisar, Shimrit. (2008). Everyone Guide to Online Dating. How to Find Love and Friendship on the Internet. Oxford: How to Books, Ltd.

Ess, Charles. (2014). Digital Media Ethics. Cambridge, UK: Polity Press. Grunebaum, James O. (2003). Friendship: Liberty, Equality, and Utility.Albany, N.Y.: State University of New York Press. 
Hongladarom, Sooraj. (2016). The Online Self: Externalism, Friendship, and Game.Switzerland: Springer.

Kant, Immanuel. (1991) The Metaphysics of Morals. Translated by Mary Gregor. Cambridge: Cambridge University Press.

Kierkegaard, Soren. (1964). Works of Love. Translated by David F. Swenson and Lilian Marvin Swenson. Princeton, N.J.: Princeton University Press.

Nietzsche, Frederick. (2001). The Gay Science. Edited by Bernard Williams, Cambridge, UK: Cambridge University Press.

Pangle, Lorraine Smith. (2003). Aristotle and the Philosophy of Friendship. Cambridge, UK: Cambridge University Press.

Price, A. W. (1989). Love and Friendship in Plato and Aristoteles. Oxford and New York: Oxford University Press.

Rooksby, Emma (2002). E-mail and Ethics: Style and ethical relations in computer-mediated-communication. London and New York: Routledge.

Vernon, Mark. ([2005] 2007). The Philosophy of Friendship. London: Pelgrave Macmillan. 